\title{
Estimating Entrance Fee of Sendang Gile Water Fall for State Based Recreation
}

\author{
Kresno Agus Hendarto \\ Rubangi Al Hasan \\ Yumantoko Yumantoko
}

Ahmad Nur

\begin{abstract}
The government decision to increase entrance fee in tourist locations has occasionally resulted in protests among the public and tourism operators. The objective of the study, with the context at Sendang Gile water fall, is to estimate the function of recreation demand and estimate the entrance fee acceptable by the visitors. Travel cost method was used in the study. Data of visitors to the tourist destination was collected by purposive sampling method. Results of the study showed that entrance fee increase is acceptable but at the rate lower than that determined in the Government Regulation.
\end{abstract}

Keywords: Travel cost methods, consumer surplus, Sendang Gile Water Fall

\begin{abstract}
ABSTRAK
Kenaikan tarif masuk lokasi wisata yang ditetapkan oleh Pemerintah tidak jarang menimbulkan protes masyarakat dan pelaku wisata di lokasi wisata tersebut. Dengan mengambil konteks lokasi wisata Air Terjun Sendang Gile, tujuan penelitian ini adalah mengestimasi fungsi permintaan rekreasi dan mengestimasi nilai tarif masuk yang dapat diterima oleh pengunjung. Metode travel cost digunakan pada penelitian ini. Data pengunjung, dengan menggunakan metode pengambilan sampel purposif, dikumpulkan di lokasi wisata. Hasil menunjukan bahwa kenaikan tarif dapat dilakukan saat ini, namun tingginya kenaikan tersebut tidak sebesar yang telah ditetapkan berdasarkan Peraturan Pemerintah.
\end{abstract}

Kata kunci: Travel cost methods, surplus konsumen, Air Terjun Sendang Gile

\section{INTRODUCTION}

Some people object to the increase of climbing entrance fee for Mount Ciremai from previously Rp 20.000 to Rp 50.000 per person which has been effective since 1 April 2015. Responses to such an increase were obtained from a number of mount climbers in social networks and those who were contacted via telephone by Pikiran Rakyat Daily
(Pikiran Rakyat, 7/3/2015).

Such is also the case for the climbing entrance fee to Mount Rinjani. Tempo (21/03/2014) wrote that the new climbing entrance fee to Mount Rinjani, of Rp. 250.000 for foreign tourists and Rp. 20.000 for domestic tourists, are too expensive. The entrance fee has been effective since 1 April 2014 for one person one day. The revenue from the sales of 
entrance ticket is deposited to the Ministry of Forestry as the State Non-Tax Revenue. The entrance fee increase is based on the Government Regulation No. 12/ 2014 concerning the Type and Rate of State NonTax Revenue in the Ministry of Forestry. Due to the increase, the public and tourism operator around the entrance of Mount Rinjani at Senaru- Lombok Utara and SembalunLombok Timur express their protest.

In addition to the public and tourism operators, the protests to the entrance fee increase also derive from the Government of NTB Province. They ask the Central Government to review the decision because the new rate may result in protest and believed to reduce the interest of climbing to that volcano. Upon the protest, while expecting the review, the entrance fee is temporarily set to be Rp. 150.000 for foreign tourists and Rp. 5.000 for domestic tourists. The temporary entrance fee is lower than the old one due to the lower zoning regulation from zone I to zone III (Government Regulation No. 12 / 2014).

With the context of Sendang Gile Water Fall, Senaru, Lombok Utara, this study aims at estimating the function of recreation demand and the entrance fee affordable by the visitors using travel cost methods. When the curve of recreation demand function can be estimated, the mean consumer surplus and price affordable to consumers can be determined.

\section{Travel Cost Method}

It has been falsely assumed that market price is equivalent to economic value while actually market price merely expresses minimal sum consumers are willing to pay for a particular product or service (Ha, 2007). In general, people buy goods or services only when their willingness to pay equals to or larger than the offered price (market price), although some people are really willing to pay higher than the market price. The people who are willing to pay higher price assume that the higher price reflect higher economic value.

Travel Cost Method (TCM) was initially introduced by Hotelling in 1949 and later developed by Clawson in 1959 (Latinopoulos,
2014). Further, he stated that the basic concept of TCM is that the benefits of outdoor recreation at a specific location can be derived from the demand function related to the number of visits / trips (or the number of visitors) with actual visit cost. In other words, the basic premise of TCM is that travel time and cost incurred to the location represent price of access to location. Therefore, Willingness to Pay (WTP) of the people visiting to a location can be estimated based on the number of visits they have made at different travel costs (Jala, 2015). Thus, the aggregate WTP is the optimal value affordable by tourists to gain utility.

\section{Recreation Demand Function}

Demand function describes the correlation between product price and number of product demanded by consumers. Mangan et al, (2013) stated that the general specification of demand function to visit a recreation location, where the demand is measured by the visit rate $\mathrm{Y}$ for individual is as follow: $\mathrm{Yi}$ $=\mathrm{f}(\mathrm{P}(\mathrm{Di} \mathrm{Wi} \mathrm{OCi}), \mathrm{Ai}, \mathrm{Si}, \mathrm{Vi})$. In that equation, number of individual visit $(\mathrm{Y})$ is the function of visit price $(\mathrm{P})$, recreation activity in location (A), consumer's perceived location condition (S), and characteristic of visitors (V). Price, in turn is a function of distance (D) from home to the tourist location, opportunity costs of time is calculated by individual wage (W), and such other relevant cost factors as transportation mode cost and entrance fee. The final objective of the study using TCM is to obtain the estimated welfare deriving from the utilization of recreation location. Therefore, it is clear that the equation of total demand function has to be associated to utility maximation (Kealy \& Bishop, 1986).

\section{Consumer Surplus}

Consumer surplus is the surplus or difference between total utility enjoyed by consumers from consuming some particular goods and the total expense paid by consumers to obtain particular goods (Boediono, 2013). Total utility and total expense are valued in money. Nicholson and Snyder (2012) defined consumer surplus as the added value obtained by an individual after consuming particular 
goods beyond the paid sum of money. This is clearly described in Figure 1.

Figure 1. Generalized Demand Function Showing Consumer Surplus and Travel Costs

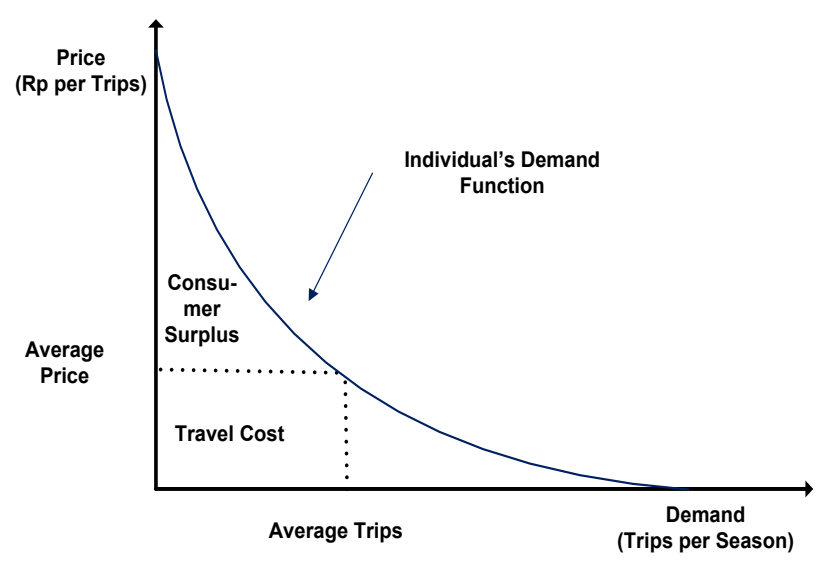

Adoption from Blaine et al, (2015)

Figure 1 shows that TCM is based on the neoclassic theory of consumer demand and based on the limited maximization of utility. Consumer surplus calculation is based on the areal extent above the travel cost. Higher mean price will lead to smaller consumer surplus, and vice versa. Meanwhile the extent of travel cost area is the actual expenditure. In TCM, several researchers use income as time cost proxy. The results showed insignificant or negative correlation between income and total demand (see among others: Weiler, 2006; Taylor et al, 2010; McKean et al, 2010, 2012) implying that income does not have impact on travel demand. In other words, higher income will not result in higher demand.

However, this study has attempted to retest whether income has effect on demand to tourist location. Therefore we specify the recraton demand model that maximize individual utility to tourist location as follow: $\mathrm{Yi}=\mathrm{f}(\mathrm{Ci}, \mathrm{Ti}, \mathrm{Qi}, \mathrm{Mi})$ where: $\mathrm{Y}=$ total visit in the past 12 months; $\mathrm{Ci}=$ Cost of travel to visit location; $\mathrm{Ti}$ = time needed to visit location; $\mathrm{Qi}$ = perception to quality of location; and $\mathrm{Mi}=$ individual income per month.

Based on the aforementioned description, the following hypotheses are proposed:

H1: Collectively variables of travel cost, time, perceived quality of location, and visitors' income have effect on total visit to location of Sendang Gile Water Fall
H2: The higher the travel cost spent by visitors, the fewer number of visits to the location of Sendang Gile Water Fall

H3: The longer the time spent by visitors to reach location, the fewer number of visits to the location of Sendang Gile Water Fall

H4: The better the quality of location is perceived by consumers, the higher the number of visits to the location of Sendang Gile Water Fall

H5: The higher the income of visitors, the higher the number of visits to the location of Sendang Gile Water Fall

\section{METHODS}

Sample

Sample was collected by purposive sampling method. Purposive sampling is the non probabilistic collection of sample meeting the particular criteria (Cooper \& Schindler, 2011). Bailey (1994) stated that the advantages of purposive sampling the use of researchers' ability and prior experiences to select respondents.

To determine the number of sample to be collected, Roscoe in Sekaran (2013) suggested the following guidelines: (1) sample size should include between 30 and 500 elements; (2) If sample is divided into sub-samples, the minimum number of sub samples should include 30 elements; (3) in multivariat study, sample size should be 10 times larger than the number of variables to be analyzed; and (4) for simple experimental study, with tight controlling, sample size may include between 10 and and 20 elements. Threfore, since there are 5 variables to be analyzed, the sample of the study consists of 50 elements. However, one of the disadvantages of TCM is insensitivity in multy trip estimation, and therefore we target 200 respondents as the sample.

\section{Measurement}

The studyemploys structured questionnaires. The questionnaires consist of two parts. The first part asks general information (for example: profile of respondents, income, source of information of tourist location, number of visits to the location in one year). The second part asks about the cost spent 
The operational definition of each variable of study can be seen in Table 1.

Table 1. Operational Definition of Variables

Variuble
Total_Visit
Trave_Cost
Travel time (Time)
Perceplion itboul
location condition
(Quality)
Visitor"y income
(Tnooms)

\section{Delinition}

Froquency of individual visit to the tourist location, measurod in total number in lie past 1 year.

Money spent for traveling from their place to the tourist location, consisling of transportition cosh, wosumption cost. and enlrance fee. all of which are ruesured in rupiah currency.

Time noded by individual to travel from their place to the tourist location. It is ruessured in boury.

: Individual's direct response to the visited lourist localion. $1 \mathrm{is}$ unolserwod wariable which is measurod by 8 items of indicator in T.ikcrt's scalc.

: Money received by individuals its the work result or money received by individuals from parents (when they have not got a job). It is measured in rupiah received per month.

by respondents to the location (for example: transportation means used to go to location, transportation cost, consumption cost, souvenir purchase cost, time needed to reach location and respondent's perception on the location). Question items were modified from previous studies conducted by Nur (2013).

When the questionnaires have been developed, the initial step taken is doing a pilot test. Pilot test is conducted to identify: (1) whether ambiguous words are present; (2) whether the instructions are understandable; (3) whether respondents find it difficult to answer; and (4) the time needed by the respondents to complete the questionnaires.

Having been revised based on the results of the pilot test; the next step is doing validity and reliability testing. Based on the level of measurement, in general variables can be divided into observed and unobserved (Gudono, 2011). Observed variable is the variable that can be directly measured from the subject; while unobserved variables cannot be directly measured from the subject (measurement is done in the indicators). From the proposed demand function, there are 4 observed variables and 1 unobserved variable. Validity and reliability were tested in unobserved variable. Validity is tested using the confirmatory factor analysis (CFA) method, while reliability was tested by finding

the Cronbach's alpha score.

Data Analysis

Data was analyzed in the following steps:

1. Eliminating the missing data, outlier and data not meeting the criteria

2. Testing classical linear regression model (classical assumption) from the data obtained. The testing includes: normality test, autocorrelation test, multicollinearity test, heteroscedasticity test, and linearity test.

3. Estimating recreation demand function of the location of Sendang Gile Water Fall and hypothesis testing

4. Calculating consumer surplus value for each level of visit frequency with the formula of $\mathrm{CS}_{\mathrm{i}}=\frac{V_{i}}{-\beta}($ Garrod and Willis, 1999) where $\mathrm{V}=$ total visit in the past 1 year.

5. Calculating visitors' sample probability for each level of visit frequency with the formula of PSample $_{i}=\frac{S_{i}}{\text { Total Sample }}$ where $S=$ total sample frequency i

6. Calculating visitors' individual probability for each level of visitors' visit frequency with the formula of PIndividual $_{i}=$ PSample $_{i} x$ Estimated Number of Total Visitors

7. Calculating Willingness to Pay (WTP) of 
the individual for each level of frequency $W_{T} P_{i}=\frac{C S_{i}}{\text { PIndividual }_{i}}$

8. Calculating aggregat WTP with the formula of $\sum_{i=1}^{n} W T P_{i}$

RESULTS

Validity and Reliability Test

Validity is tested only for unobserved variable, that is the variable of respondents' perception to the environmental quality of the visited tourist location (quality), using the method of confirmatory factor analysis. Results of validity analysis for 30 respondents show that all question items were valid. This is shown with the loading factor value of each question item in quality variable over 0.5 ; which is valid when the loading factor score is higher than 0.5 (Hair, et al., 2010).

When validity has been tested, the next step is reliability testing. Reliability is tested by calculating internal consistency (cronbach's alpha). Several authors state that Cronbach's Alpha value higher than 0.6 is reliable (see, for example: Jogiyanto and Abdillah (2009); Nunnaly in Ghozali (2005). Results of calculation show cronbach's alpha value of 0.862; implying that all indicators for quality variable are reliable. Validity and reliability testing results are presented in Table 1.

Table 1. Output of the Validity and Reliability Test for Quality

\begin{tabular}{|c|c|c|}
\hline & $\begin{array}{l}\text { Variable }(\mathrm{n}= \\
\text { Loading } \\
\text { Factor }\end{array}$ & $\begin{array}{c}\text { Cronbach's } \\
\text { Alpha }\end{array}$ \\
\hline Itcm-1 & 0.702 & 0.862 \\
\hline 1tem-2 & 0.571 & \\
\hline ltem-3 & 0.515 & \\
\hline Itcm-4 & 0.765 & \\
\hline Itcm- 5 & 0.676 & \\
\hline 1tem- 6 & 0.903 & \\
\hline ltem- 7 & 0.690 & \\
\hline ltem-8 & 0.871 & \\
\hline
\end{tabular}

Profile of Respondents

Of the 200 questionnaires distributed, only 164 (response rate $=82 \%$ ) were eligible for further analysis. The remaining questionnaires could not be analyzed because: (1) several questionnaires were missing; (2) failure to complete the question item related to the variable to be studied; and (3) if completed, respondent's response was outlier. Gudono (2011) stated that the presence of outlier may result in bias, that is, the estimate regression coefficient will be biased to the outlier point. Outlier data was eliminated by calculating zdata (data standardization). If the data standardization value is higher than 2.5 or lower than 2.5 then it is expected that the data is outlier and thus it is excluded from the analysis (Santoso, 2002).

Table 2 show that profile of respondents becoming the sample is: (1) that most of the respondents are male; (2) more than half of the respondents graduated from senior high school; (3) most of the respondents domicile in Mataram; and (4) more than half of the respondents were aged between 20 and 30 years.

\section{Classic Assumption Test}

Classic assumption testing from the data obtained include: normality test, autocorrelation test, multicollinearity test, heteroscedasticity test, and linearity test. Results of the classic assumption test are as follow:

1. Normality was tested with Skewness and Kurtosis test. Data is normally distributed when the ratios of Skewness and Kurtosis are in the range of -2 and +2 . Results of analysis revealed the ratio of Skewness $=4.29$ and ratio of Kurtosis $=1.28$; this implies that the obtained data wasnot normally distributed.

2. Autocorrelation was tested with DurbinWatson test. Results of calculation revealed that the statistic value of Durbin-Watson was 0.130 . The value of DW table with $\square=5 \%$ and $\mathrm{N}=186$ was $\mathrm{dL}=1.7153$ and $\mathrm{dU}=1.8041$. since the value of DW is lower than $\mathrm{dL}$, it is assumed that positive autocorrelation existed. 3. Multicollinierity was tested by calculating the value of Variance Inflation Factor (VIF). 
Table 2. Respondent Demographic Profile $(n=164)$

\begin{tabular}{|c|c|c|c|}
\hline Foriable & Perceuts & Tarizble & Proceutins \\
\hline Cimilur & & $t_{\mathbf{p}}$ & \\
\hline$M \mid z=$ & 55.19 & $r: 20$ & 21.39 \\
\hline \multirow[t]{4}{*}{ Iemal: } & +1.51 & $20-30$ & 57.4 \\
\hline & & 4 4i: & 11 \\
\hline & & $11-50$ & 5.10 \\
\hline & & 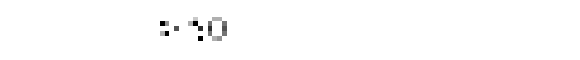 & - \\
\hline Faluselinn & \multicolumn{2}{|r|}{ Ihamiail. } & \\
\hline Primsry School & 0.61 & Lombat: Dur: & 1.63 \\
\hline $\begin{array}{l}\text { Tunioc [liagh } \\
\text { Sirlla:ml }\end{array}$ & ati & I anthak. Tingesh & $m 1 \%$ \\
\hline $\begin{array}{l}\text { Senior L-izh } \\
\text { silla: }\end{array}$ & otí & I anuluth Tim & נהים \\
\hline \multirow[t]{3}{*}{ T-aines: } & 29.87 & Lombok: Dtars & 18.29 \\
\hline & - & Mularin & Ditis \\
\hline & & Orvide of Lambok :sland & 3.60 \\
\hline
\end{tabular}

Table 2 show that profile of respondents becoming the sample is: (1) that most of the respondents are male; (2) more than half of the respondents graduated from senior high school; (3) most of the respondents domicile in Mataram; and (4) more than half of the respondents were aged between 20 and 30 years.

Results of testing revealed that the value of VIF was lower than 10 (several books require the value of VIF less than 5). Therefore, it can be concluded that the data had no multicollinearity problem.

4. Heteroscedasticity occurred when the residual and prediction value are correlated. Results of analisis of data showed that t-statistic value was significant for independent variable of Time. This implied that there was heteroscedasticity problem for independent variable of Time.

5. Linearity test results showed that thetstatistic value of Deviation for Linearity was significant for the variable Total_Visit * Time. This implies that variable of Time was not linear to dependent variable of Total_Visit.

The classic assumption test results are summarized in Table 3.
Tabel 3. Results of the Classic Asumption Test

\begin{tabular}{|c|c|c|}
\hline No & $\begin{array}{c}\text { Classic } \\
\text { Assumption }\end{array}$ & Results \\
\hline 1 & Normality & Not appropriate \\
2 & Autocorrelation & Positive \\
3 & Multicollinearity & Appropriate \\
4 & Heteroscedasticity & Not appropriate \\
5 & Linearity & Not appropriate \\
\hline
\end{tabular}

Multiple Linear Regression with Logarithmic Transformations Test

Table 3 shows that the collected data only partially meet the classic assumption. Several researchers have transformed the model to process the data (see, for example, Styneset al, 1986; von Haefen and Phaneuf, 2003). What we did later was transforming the model from Lin-Lin to Log-Lin (semi log). The general model of Log-Lin model can be written as follow: 
Tabel 4. Results of the Log-Lin Regression Analysis

\begin{tabular}{|llrrrrr|}
\hline Model & & $\begin{array}{c}\text { Sum of } \\
\text { Squares }\end{array}$ & \multicolumn{1}{c}{ df } & $\begin{array}{c}\text { Mean } \\
\text { Square }\end{array}$ & \multicolumn{1}{c|}{ F } & Sig. \\
\hline & Regression & 3.510 & 4 & .878 & 4.187 & $.003^{\mathrm{a}}$ \\
Residual & 33.326 & 159 & .210 & & \\
Total & 36.836 & 163 & & & \\
\hline
\end{tabular}

Note: a. Predictors are (Constant), Travel_Cost, Quality, Time, Income b. The dependent Variable is Ln_Total_Visit

\begin{tabular}{|llrrrr|}
\hline \multirow{2}{*}{ Mode1 } & \multicolumn{7}{c}{$\begin{array}{c}\text { Unstandardized } \\
\text { Coefficients }\end{array}$} & $\begin{array}{c}\text { Standardized } \\
\text { Coefficients } \\
\text { Beta }\end{array}$ & B & Std. Error & T & Sig. \\
\hline \multirow{2}{*}{ (Constant) } & 1.137 & .585 & & & \\
Income & .054 & .042 & .112 & 1.309 & .192 \\
Quality & .197 & .094 & .160 & 2.088 & .038 \\
Time & -.259 & .099 & -.200 & -2.613 & .010 \\
Travel Cost & $-7.109 \mathrm{E}-7$ & .000 & -.183 & -2.110 & .036 \\
\hline
\end{tabular}

\section{$\log \left(Y_{i}\right)=\beta_{0}+\beta_{1} x_{i 1}+\beta_{2} x_{i 2}+\ldots+\beta_{k} x_{k}$}

Results of Log-Lin regression analysis for all variables are presented in Table 4.

Table 4 shows that collectively, independent variables in the model have significant effects on dependent variable (hypothesis 1 was accepted). Table 4 also shows how much an independent variable effect can individually explain the variation of dependent variable. Partially, variable of individual's income did not significantly have effect on the total tourist visit in Sendang Gile Water Fall (hypothesis 5 was rejected). Meanwhile, variables of quality, time, and cost have significant effect (hypothesis 2, 3 and 4 were accepted).

\section{Consumer Surplus}

Estimation of consumer surplus of visit per individual and WTP can be seen in Table 5 .

\section{Discussion}

The objective of this study is to estimate demand function of recreation in the recreational location of Sendang Gile Water Fall. Classic assumption test aims at ensuring that the estimate, with the data collected, is not biased (and consistent) with either large or small sample size (Gujarati, 2004). Because the testing results show that the collected data did not meet the classic assumption (see Table 3) we transformed the data. Data was transformed from Lin-Lin to Log-Lin (semi log).
Results of testing of the 5 hypothesis suggest that 1 hypothesis (hypothesis 5) was rejected. Hypothesis 5 states that "higher income of visitors lead to higher visit to the location." In other words, this study indicates that higher income of individual did not have effect on the visit to Sendang Gile Water Fall. Although it is not significant, for the sample of this study, direction of income variable was negative. This is in line with the demand law stating that in ceteris paribus, demand for particular goods will decrease when price of the goods increases (Mankiw et al, 2014). The finding that variable of income had no effect on total visit to location of Air Terjun Sendang Gile strengthen previous researches conducted by Weiler (2006); Taylor et al, (2010); McKean et al, (2010, 2012).

The second objective of this study is to estimate the rate of entrance fee to the location of Sendang Gile Water Fall. Results of the analysis show that higher frequency of individual's visit to recreation location will lead to higher consumer surplus. This is in line with the value of WTP (see Table 5). WTP is willingness to pay (Irawan, 2009). Table 5 also shows that the value of aggregat WTP is Rp. 8336.34. This show that visitors are still wililng to pay higher price than the current price of Rp 5.000.

\section{CONCLUSIONS,}

LIMITATIONS

AND SUGGESTIONS

\section{Conclusions}

There are two objectives of this study. The first 
Table 5. Results of the Consumer Surplus and Willingness to Pay Estimate

\begin{tabular}{|c|c|c|c|c|c|}
\hline $\mathbf{N}$ & $\begin{array}{c}\text { Beta of } \\
\text { travel } \\
\text { cost }\end{array}$ & $\begin{array}{c}\text { Consumer } \\
\text { Surplus }\end{array}$ & Probability & $\begin{array}{c}\text { Probability } \mathbf{x} \\
\text { estimated } \\
\text { number of } \\
\text { total visitors }\end{array}$ & $\begin{array}{c}\text { Willingness to } \\
\text { Pay }\end{array}$ \\
\hline 1 & $7.11 \mathrm{E}-07$ & 1406667.60 & 0.43 & 7792.68 & 180.51 \\
2 & $7.11 \mathrm{E}-07$ & 2813335.21 & 0.34 & 6036.59 & 466.05 \\
3 & $7.11 \mathrm{E}-07$ & 4220002.81 & 0.18 & 3292.68 & 1281.63 \\
4 & $7.11 \mathrm{E}-07$ & 5626670.42 & 0.05 & 878.05 & 6408.15 \\
\hline & TOTAL & 14066676.04 & 1.00 & & 8336.34 \\
\hline
\end{tabular}

objective is to estimate demand function of recreation at the tourist destination of Sendang Gile Water Fall. The second objective is to estimate the entrance fee rate to the location of Sendang Gile Water Fall. Results of analysis show that collectively the variables of cost, time, perceived quality of the location, and individual income have effect on the total visit to Sendang Gile Water Fall. Meanwhile, only variable of income partially had no effect on the number of visits. Results of analysis of the estimate of WTP through consumer surplus value show that entrance fee rate can be increased from the current rate of Rp. 5.000 to $\mathrm{Rp} \mathrm{8.336.34}$ per visitor.

\section{Limitations and Suggestions}

This study has some limitations. First, TCM cannot estimate multi trips. With filter questions, this limitation can be reduced. Reduction of weaknesses can be done by analyzing only the visitors who have single visit. Second, This study did not consider oportunity cost. Using filter questions, this limitation can be reduced by only analyzing the visitors whose primary destination is the location. Third, This study employed purposive sampling method to ensure wider generalization although it has to be carefully managed. It is expected that randomized sampling method can be used to ensure generalization of the findings.

\section{Acknowledgements}

We gratefully acknowledge the comments made by Shine Pintor Siolemba Patiro from Gadjah Mada University., Siti Latifah, Markum, and Yayan from Mataram University., and I Made Widnyana from Balai Penelitian Teknologi Hasil Hutan Bukan
Kayu Mataram, as well as the anonymous reviewers for their comments on this article.

\section{References}

Bailey, K.D. 1994. Methods of social research, 4th ed., New York: the Free Press.

Blaine, T.W., Lichtkoppler, F.R., Bader, T.J., Hartman, T.J., and Lucente, J.E. 2015. An examination of sources of sensitivity of consumer surplus estimates in travel cost models. Journal of Environment Management. 151: 427-436.

Boediono. 2013. Ekonomi mikro, edisi ke 2.

Yogyakarta: BPFE.

Cooper, D.R. and Schindler, P.S. 2011. Business research methods, 11 th ed. Singapore: McGrawHill International Edition.

Garrod, G and Willis, K.G. 1999. Economic valuation of the environment: method and case studies. Massachusetts: Edward Elgar Publishing. Ghozali, I. 2005. Aplikasi analisis multivariate dengan program SPSS. Semarang: Badan Penerbit Universitas Diponegoro.

Gudono. 2011. Analisis data multivariat.

Yogyakarta: BPFE.

Gujarati, D.N. 2004. Basic Econometrics, 4th ed.

New York: McGraw Hill.

Ha, I.S. 2007. Recreation Demand for A Gulf Coast Tourism Destination. Jourmal of Economics and Economic Education Research, 8(1): 51-65.

Hair, J.F., Black, W.C., Babin, B.J., and Anderson, R.E. 2010. Multivariate Data Analysis: A Global Perspective, 7th ed., New Jersey: Pearson Prentice Hall.

Irawan, D.H. 2009. Willingness to Pay dan Ability to Pay pelanggan rumah tangga sebagai respon terhadap pelayanan air bersih PDAM Kota 
Surakarta. Jejak 2 (1): 29-43.

Jala and Nandagiri, L. 2015. Evaluation of economic value of pilikula lake using travel cost and contingent valuation methods. Aquatic Procedia. 4: 1315-1321.

Jogiyanto, H.M., and Abdillah, W. 2009. Konsep dan aplikasi PLS untuk penelitian empiris. Yogyakarta: Badan Penerbit Fakultas Ekonomika dan Bisnis UGM.

Kealy, M.J., and Bishop, R.C. 1986. Theoretical and Empirical Specifications Issues in Travel Cost Demand Studies. American Journal of Agricultural Economic. 68(3), 660-667.

Latinopoulos, D. 2014. The impact of economic recession on outdoor recreation demand: an application of the travel cost method in Greece. Journal of Environmental Planning and Management. 57(2), 254-272.

Mangan, T., Brouwer, R., Lohano, H.D. and Nangraj, G.M. 2013. Estimating the recreational value of pakistan;s largest freshwater lake to support sustainable tourism managemet using a travel cost model. Journal of Sustainable Tourism. 21(3): 473-481.

Mankiw, N.G., Quah, E., and Wilson, P. 2014. Principles of Economics: An Asia Edition, 2nd ed. Singapore: Cengage.

McKean, J.R., Johnson, D., and Taylor, R.G. (2010). Willingness-to-pay for steelhead trout fishing: Implications of two-step consumer decisions with short-run endowments. Water Resources Research. 46: 1-11.

-------. 2012. Three approach to time valuation in recreation demand: A study of the Snake River recreation area in eastern Washington. Journal of Environmental Management. 112: 321-329. 